\title{
Kavram Yanılgıları ile Yanıtlayıcı Davranışları Arasındaki İlişkilerin Matematik Okuryazarlığı Örneği Üzerinde İncelenmesi ${ }^{1}$
}

\begin{tabular}{lccc}
\hline MAKALE TÜRÜ & Başvuru Tarihi & Kabul Tarihi & Yayın Tarihi \\
Araştırma Makalesi & 18.12 .2018 & 04.12 .2019 & 01.04 .2020 \\
\hline
\end{tabular}

\author{
Emre Kucam \\ Özel Zafer Koleji
}

\author{
Ergül Demir (iD) 3 \\ Ankara Üniversitesi
}

\begin{abstract}
Öz
$\mathrm{Bu}$ araştırma, ortaokul sekizinci sınıf öğrencilerinde matematik okuryazarlığı becerileri kapsamındaki kavram yanılgıları ile bu becerileri ölçmeye yönelik bir testteki yanıtlayıcı davranışları arasındaki ilişkileri belirlemek amacıyla yürütülmüştür. Çalışma, ilişkisel araştırma modelindedir. Araştırmanın örneklemini, Ankara ilinin Çankaya, Etimesgut ve Yenimahalle ilçelerinde bulunan üç okulun sekizinci sınıflarında öğrenim gören 340 ögrenci oluşturmaktadır. Araştırmada, öğrencilere ilişkin veri toplamak amacıyla araştırmacı tarafından geliştirilmiş Kişisel Bilgi Formu, öğrencilerin matematik okuryazarlığı kapsamındaki kavram yanılgılarını belirlemek amacıyla İki Aşamalı Tanı Testi ve iki aşamalı tanı testindeki maddelerin nasıl yanıtlandığının belirlenmesi amacıyla Yanıtlayıcı Davranışları Formu kullanılmıştır. Araştırmadan elde edilen veriler, betimsel istatistiklere dayalı incelemenin yanı sıra ki-kare bağımsızlık testi ile analiz edilmiştir. Araştırma bulguları; kavram yanılgısı olan öğrencilerin yanıtlamada çoğunlukla eleme davranışını kullandıklarını, kavram yanılgısı olmayan öğrencilerin ise işlem yapma ve eleme davranışını kullandıklarını göstermektedir. Kavram yanılgısı türlerine göre yanıtlayıcı davranışları ele alındığında, aşırı özelleme kavram yanılgısına sahip olduğu gözlenen öğrencilerin, yanıtlamada en çok rastgele işaretleme davranışını kullandıkları, diğer kavram yanılgısı türlerinde ise en çok eleme davranışını kullandıkları belirlenmiştir. Ayrıca kavram yanılgısı türlerinin ve yanıtlayıcı davranışlarının cinsiyete göre anlamlı farklılık göstermediği ve öğrencilerin yanıtlayıcı davranışlarının, bulundukları ilçeye göre farklılaşmadığı belirlenmiştir.
\end{abstract}

Anahtar sözcükler: Kavram yanılgısı, yanıtlayıcı davranışları, matematik okuryazarlığı, iki aşamalı tanı testi.

${ }^{1}$ Bu makale birinci yazarın yüksek lisans tezinden yararlanılarak üretilmiştir.

${ }^{2}$ Sorumlu Yazar: Uzman, E-posta: emrekucam@ gmail.com, https://orcid.org/0000-0002-4283-7103

${ }^{3}$ Doç. Dr., Eğitim Bilimleri Fakültesi, Eğitim Bilimleri Bölümü, Eğitimde Ölçme ve Değerlendirme Anabilim Dal1, E-posta: erguldemir@ankara.edu.tr, https://orcid.org/0000-0002-3708-8013 
Bireyler arasındaki farkların ne kadarının gerçek olduğunu ve ne kadarının ölçme sonucuna karışan hatalar içerdiğini belirleyebilmek, güvenirlik sorunu olduğu kadar aynı zamanda bir geçerlik sorunudur. Bu farklılıkları vurgulamak ve yüksek performans (edim) gösteren öğrencileri, okulları ve eğitim sistemlerinin özelliklerini ortaya çıkarmak amacıyla öğrenme çıktılarıyla ilgili veriler ile, okul-çevre etkileşimiyle öğrenmeyi biçimlendiren etkenlerle ilgili veriler arasında bir ilişki kuran eğitim politikalarının benimsenmesi gerekmektedir (Organization for Economic Cooperation and Development-OECD, 2006). Bu nedenle de belirli aralıklarla düzenli ölçme ve değerlendirmelerin yapılması, ülkelerin temel eğitim hedeflerine ulaşma düzeylerini belirlemeleri açısından önemlidir. $\mathrm{Bu}$ düzenli ölçme ve değerlendirmelerin bilişsel boyutlarının yanı sıra duyuşsal boyutlarının da olması, yapılan değerlendirmelerin yaşam boyu öğrenmeyle ilişkilendirilmesi açısından daha geçerli çıktıların elde edilmesini sağlayacaktır (Yenilmez ve Ata, 2013). Böylece öğrenme çıktılarıyla okul içinde ya da dışında öğrenmeyi şekillendiren etkenler arasındaki açıklık, daralmaya başlayacaktır. Bu açıklığı oluşturan, kavramlarla ilgili geliştirilen yanılgılardır.

Uzmanların bir konuyla ilgili alanyazında hemfikir oldukları görüşün uzağında kalan algı ya da kavrayışlar, kavram yanılgısı olarak adlandırılmaktadır (Hammer, 1996). Kavram yanılgıları, bilimsel otoritelerce kabul görmüş kavramlara alternatif olarak bireyler tarafından geliştirilen tanımlamalardır (Tekkaya, Çapa ve Yılmaz, 2000). Burada sözü edilen, bireylerin kendi kendilerine geliştirdikleri kavramların ne olarak anlaşıldığı, otoritelerce kabul görmüş bilimsel anlamından ne derecede uzaklaştı̆̆ıdır. Kavram yanılgıları, öğrencilerin eski öğrenmelerine ait olabileceği gibi, öğrenim süreci içinde de oluşabilir. Ayrıca kavram yanılgısına öğrencideki bazı sezgiler ile ön yargılar da neden olabilmektedir. Bu sezgiler de bilimsel kavramların tam ve doğru ifadelerinin öğrencilere kazandırılamamasına neden olmaktadır.

Kavram yanılgılarının benzer özelliklerinin belirtildiği çalışmalarda (Fisher, 1985; Hammer, 1996; Nachtigall, 1990) ortak olarak vurgulanan özellikler; her bireyin kendine göre ve belli bir sistematik olmaksızın kavram yanılgısı geliştirebileceği, kavram yanılgılarının bilimsel bilgiden uzak ve doğru bilgiye dirençli olduğu ve bireyin sadece okulda değil tüm çevresel etkileşimlerde kavram yanılgıları geliştirebileceği olarak belirtilebilir. Bu kapsamda kavram yanılgılarını matematik özelinde ele alan Graeber ve Johnson (1991), kavram yanılgısına neden olan durumları daha uygun şekilde dört ayrı kategoride ele almıştır. Bu araştırmada da kavram yanılgısı türleri olarak ele alınan kategoriler; aşırı genelleme, aşırı özelleme, yanlış tercüme ve kısıtlı algılama olarak sınıflandırılmıştır. Aşırı genelleme; belli bir sınıfa ait bir kuralın, ilkenin (prensibin) veya kavramın diğer sınıflarda da geçerliymiş gibi düşünülerek diğer sınıflara da yayılmasıdır. Örneğin, "Pozitif bir sayının önüne gelen negatif işareti bu sayıyı negatif yapar" kuralı dikkate alındığında, yaygın yanılgılardan biri, bu kuralın "-a negatiftir” biçimine dönüştürülerek aşırı bir şekilde tüm sayılara genellenmesi, aşırı genellemedir. Aşırı özelleme; belli bir sınıfa ait bir kurala, bir ilkeye ya da kavrama o sınıfin tümüne ait olmayan bir özelliği temel alarak bir kısıtlama koyulmasıdır. Örneğin, değişme özelliğinin, sadece doğal 
sayılarla yapılan işlemlerde kullanıldığını belirtmek, reel sayılar için uygulanan bir kuralı bir alt küme olan doğal sayılara aşırı özellemektir. Yanlış tercüme; cümle, formül, grafik, işlem, sembol ve tablo gibi birbirinden farklı ifade biçimleri arası geçişlerde yapılan sistemli hatalar zinciridir. Kısıtlı algılama (kavrayış); bir kavramın kısıtlı (veya olması gerekenden zayıf) olarak anlaşılması, bu kavramın kısıtlı olarak algılanmasına neden olur. Örneğin, kesirler konusunda bir bütünü üç parçaya bölüp birini almak denilince öğrencinin, bölünen parçaların eş olması gerektiğini düşünememesi kısıtlı algılama olarak adlandırılır. Dolayısıyla herhangi şekilde bölünen ve eş olmayan üç parçadan birini alması kısıtlı algılamadır. Bu kategoriler incelendiğinde, bireylerde var olan yanılgıların belirlenerek sınıflandırılması önem kazanmaktadır.

Kavram yanılgılarını belirlemek için yapılan çeşitli araştırmalar incelendiğinde (Akdemir, 2005; Coştu, Ayas ve Ünal, 2007; Palut, 2006) kavram yanılgısını belirlemede farklı yöntemlerin bulunduğu görülmektedir. Bunlar, bireydeki kavram yanılgısıyla ilgili bir kanı oluşturan ve belge niteliği taşıyan yöntemler olarak ikiye ayrılabilir. $\mathrm{Bu}$ kapsamda yapılan bazı araştırmalarda tamamlayıcı ölçme ve değerlendirme araçlarının (V diyagramları, kavram haritaları, kavram karikatürleri, mülakatlar, çizimler vb.) kullanıldığı görülmektedir. Bu yöntemlere ek olarak alanyazında, kavram yanılgısı belirlemede çeşitli testlerin de kullanıldığı çalışmalara rastlanmaktadır (Çakır ve Aldemir, 2011; Çetin ve Günay, 2010; Karataş, Köse ve Coştu, 2003; Yılmaz ve Morgil, 2001). Genellikle bu çalışmalarda kavram yanılgılarını belirlemek amacıyla kullanılacak testler, araştırmacılar tarafindan geliştirilmiştir. Elde edilen sonuçlar ise öğrencilerin belirli kavramları anlamada zorlandığını ve çeşitli yanılgılara sahip olduğunu göstermiştir.

Alanyazın incelendiğinde kavram yanılgılarının belirlenmesinde kullanılan yöntemlerden birinin sözlü yoklama olduğu görülmektedir. Ancak sözlü yoklama, uygulama ve bulguların yorumlanması sırasında karşılaşılan birtakım güçlükler içermektedir. Bundan dolayı sözlü yoklamalar yerine yaygın olarak seçmeli testlerin kullanımı tercih edilmektedir (White, Gunstone ve Oversby, 1994). Ancak öğrencinin işaretlediği seçeneği hangi bilişsel süreçleri kullanarak seçtiğini ve seçme nedenlerinin neler olduğunu belirleme olanağı yoktur. Bu ve benzeri sinırlılıkları giderebilmek amacıyla çoktan seçmeli testlerin olumlu yönlerini büyük ölçüde barındıran ve olumsuz yönlerini en aza indiren, özellikle 70'li yılların sonlarından bu yana birçok araştırmacı tarafından daha çok fen bilimlerinin farklı alanlarında iki aşamalı tanı testleri kullanılmaktadır (Garnett ve Treagust, 1992).

İki aşamalı testlerin birinci ve ikinci aşamalarının sırasıyla çoktan seçmeli çoktan seçmeli, çoktan seçmeli - açık uçlu, doğru yanlış - çoktan seçmeli ve doğru yanlış - açık uçlu maddelerden oluştuğu çalışmalara rastlanmaktadır (Atasoy ve Akdeniz, 2007; Çakır ve Aldemir, 2011; Gürdal, 2008; Karataş ve diğ., 2003; Kenan ve Özmen, 2014; Özkan ve Bal, 2017; Uğur, 2010). Bu çalışmalar incelendiğinde, ilk aşaması çoktan seçmeli ve ikinci aşaması açık uçlu olarak oluşturulmuş iki aşamalı tanı testlerinin analizinde 1-0 şeklinde iki kategorili puanlama yapılmasının, 
öğrencilerin kavramları anlama düzeylerini ve kavram yanılgılarına sahip olma durumlarını belirlemede yeterli olmayacağı görülmektedir. Bu kapsamda, iki aşamalı tanı testlerinin her iki aşamasının puanlanması da birbirinden farklılaşmaktadır.

$\mathrm{Bu}$ aşamalarda, iki aşamalı tanı testinin öncelikle konu içeriğinin belirlenmesine vurgu yapıldığı görülmektedir. Bu içerik belirlenirken ders kitapları ve öğretim programları incelenerek ilgili konu veya kavramı yansıtacak önermelerin oluşturulmasının gerekliliği de ifade edilmektedir. Daha sonra ise, öğrencilerin kavram yanılgılarının alanyazın incelemeleri veya sözlü yoklamalar ile belirlenme durumlarından söz edilmekte ve ardından maddelerin geliştirilme aşamaları dile getirilmektedir. Önerilen bu aşamalar birlikte ele alındığında iki aşamalı tanı testlerinin kullanılmasının amacının, öğrencilerin kavram yanılgıların belirlemek olduğu görülmektedir (Garnett ve Treagust, 1992). Ancak bu yanılgıların tam olarak belirlenmesi için, ilgili kavram yanılgılarının doğasının anlaşılması ve maddelere yönelik yanıtlayıcı davranışlarının bu yanılgılarla eşleştirilmesinin gerektiği düşünülmektedir.

Bellekten geri çağırılacak bilgilerin yeterli olduğunun düşünülmesine neden olan kavram yanılgılarının ortaya çıkarabileceği yanıtlayıcı davranışları, maddelerin psikometrik özelliklerini etkileyen değişkenlerin ve şans başarısının hangi durumlarda daha çok ortaya çıktığını daha iyi açıklayabilecektir. Bu nedenle çoktan seçmeli maddelerden oluşan testlerde maddelerin ne zaman ve nasıl okunduğu, okunduktan sonra hangi davranışlar gösterilerek yanıtın bulunmaya çalışıldığı ve bu sırada hangi bilişsel süreçlerin ortaya çıktığı belirlenmelidir. Ölçülmek istenen davranışı en iyi ölçecek maddelerin hazırlanabilmesi ve ölçmedeki hata payının en aza indirilebilmesi ile bilişsel yeterliklerin davranışa dönüşme sürecinin ortaya çıkarılabilmesi açısından yanıtlayıcı davranışlarının açıklanabilmesi gerekmektedir (Pehlivan ve Kutlu, 2014). $\mathrm{Bu}$ davranışların temelde dört grupta toplanabileceği görülmektedir. İlki, yanıtlayıcının ölçülen davranışa sahip olma durumunda, gerekli basamakları izleyerek maddeyi yanıtlama durumudur. Diğeri, yanıtlayıcının ölçülen davranışa kısmen sahip olma durumunda bilgilerini kullanarak seçeneklerden bazılarını elemesi ve ölçülen davranışa ilişkin bilgilerini tekrar gözden geçirerek maddeyi yanıtlaması durumudur. Bir diğer davranış grubu, yanıtlayıcının ölçülen davranışa sahip olmama durumunda, doğru yanıtı bulmak adına çeşitli davranışların sergilendiği, yanıtlayıcının maddeyi bilmeyerek yanıtlama durumudur. Son davranış grubu da ölçülen davranışa sahip olmama ya da herhangi nedenle maddeye erişilememesi durumunda yanitlama yapılmamasıdır (Turgut, 1971). Kısaca, yanıtlayıcının doğru yanıtı bulma çabası ya da boş bırakması durumunu yanıtlayıcı davranışları olarak nitelendirmek mümkündür. Bu davranışların doğası incelendiğinde; yanıtlayıcıların, davranışa sahip olma durumunda yaptıkları işaretlemelerin doğru olduğunu düşünmeleri, diğer durumlarda ise yaptıkları işaretlemelerden emin olmamaları beklenmektedir. Buradan hareketle çoktan seçmeli testlerde yapılan işaretlemenin doğru olması durumunda yanıtlayıcının beklenen davranışa kesinlikle sahip olduğu söylenemez. $\mathrm{Bu}$ ise, herhangi bir şekilde doğru yanıtlanan madde ile ilgili kavram yanılgısı kuşkusunu ortaya çıkarmaktadır. Yanıtlayıcı davranışlarının belirlenmesi, bireylerin maddeleri 
yanıtlarken gerçekleşen bilişsel süreçlerini tanıma olarak belirtildiğinde, bilişsel süreç basamakları önem kazanmaktadır. Bu bağlamda sadece temel düzeyde değil, üst düzeydeki beceriler ölçülürken de yanıtlayıcıların maddeleri yanıtlarken gösterdiği davranışların belirlenmesi gerekmektedir. Nitekim, ölçme ve değerlendirmenin sürekli ve sürece yayılmış olması bağlamında yenilenen ilköğretim programları değerlendirildiğinde, üst düzey düşünme becerilerinin gündelik yaşam ile ilişki kurularak geliştirilmesi ve ölçülmesi önem kazanmaktadır (Demirtaşlı, 2010). Bu bağlamda, problem çözme sürecinin, karar verme gibi üst düzey düşünme becerisi gerektirdiği düşünüldüğünde, uluslararası ölçme uygulamalarında (Trends in International Mathematics and Science Study-TIMSS, Programme for International Student Assessment-PISA, ...) matematik ve fen alanlarında; yorumlama ve karar verme gibi üst düzey düşünme becerilerinin gündelik yaşam durumlarında yoklandığ 1 görülmektedir. Buradan hareketle matematiğin günlük yaşamda kullanımını ifade eden ve üst düzey düşünme becerilerini harekete geçiren matematik okuryazarlı̆g 1 kavramı ortaya çıkmaktadır.

Bireylerin, temel yeterlik ve becerilerini belli oranda kazanması ve çeşitli sorunlara çözüm getirebilme derecesi, matematik okuryazarlı̆̆ının düzeyini göstermekle birlikte bu düzeyi düşürme eğiliminde olan ve bireyin eğitim yaşamını oluşturan etkenlere bağlı çeşitli engeller söz konusu olabilmektedir. Bu engellerden biri kavram yanılgılarıdır. Yapılan araştırmalar incelendiğinde, matematik ile ilgili kavram yanılgılarının alanyazında diğer alanlardan daha geniş bir yer kapladı̆̆ 1 görülmektedir (Ayylldı, 2010; Baki ve Güç 2014; Kaygusuz, 2011; Reys, Reys ve Penafiel, 1991). Matematiğin, diğer alanlardan daha soyut olmasının, bunda önemli bir payının olduğu düşünülmektedir. Bu pay göz önüne alındığında, öğrencilerin yanıtlayıcı davranışları ile kavram yanılgıları arasındaki ilişkinin belirlenmesinin gerekliliği öne çıkmaktadır. Araştırmada, yanıtlarının doğruluğuna inanan öğrencilerin, kavram yanılgıları nedeniyle inandıkları bu gerekçelendirmeler ile ilgili genel durum belirlenmek istenmiştir. Alanyazın incelendiğinde ise kavram yanılgılarına ve yanıtlayıcı davranışlarına ait ayrı ayrı çalışmaların var olduğu görülmektedir. Ancak alanyazında kavram yanılgılarıyla yanıtlayıcı davranışlarının birlikte ele alındığı bir çalışmaya rastlanmamıştır.

Türkiye'de ve dünyada kavram yanılgısı ile ilgili yapılan araştırmaların sayısı fazla olmakla birlikte, aşamalı tanı testlerinin (Chandrasegaran, Treagust ve Mocerino 2007; Çakır ve Aldemir, 2011; Haslam ve Treagust, 1987; Milenkovic, Hrin, Segedinac ve Horvat 2016; Taşlıdere, Korur ve Eryılmaz 2012) ve yanıtlayıcı davranışlarının (Delgado ve Prieto, 2004; Kadıŏlu, 2002; Koçak, 2013; Pehlivan ve Kutlu, 2014; Reys ve diğ., 1991; Şimşek ve Kutlu, 2017; Tokat, 2006; Umay, 1998) ele alındığ araştırmalar daha azdır. Kavram yanılgıları ile ilgili bu araştırmalar bir bütün olarak ele alındığında, yanılgıları belirlemek için genellikle iki aşamalı testlerin kullanıldığı ve bu testlerdeki maddelere verilen yanıtlara göre, kavram yanılgısı düzey ve durumlarının araştırmacı tarafından belirlenen ölçütlere göre saptandığ 1 görülmektedir. Ayrıca, iki aşamalı tanı testlerinde öğrencinin maddeleri yanıtladıktan sonra yanıtının gerekçesini açıkladığı ayrı bir aşamanın olmasının; üç aşamalı 
testlerde ise buna ek olarak verdiği yanıttan emin olma durumunun sorgulanmasının, kavram yanılgılarının daha sağlıklı belirlenebilmesi açısından önemli olduğu bilinmektedir. Yanıtlayıcı davranışları ile ilgili olan araştırmalarda ise, çoktan seçmeli ve açık uçlu sorulardan oluşan başarı testlerindeki yanıtlayıcı davranışları, değişik yaş grupları üzerinde farklı yöntemlerle belirlenmeye çalışılmıştır. Araştırmaların sonucunda ise yanıtlayıcı davranışları; yaş grubu, sınav türü, şans başarısı ve test maddesi özellikleri doğrultusunda açıklanmaya çalışılışstır. Ayrıca dikkati çeken diğer bir durum da yanıtlayıcı davranışlarının, çoğunlukla problem çözme süreci başlı̆ı̆ altında matematik alanında incelenmesidir. Buradan hareketle bireylerin kavram yanılgılarının yanıtlayıcı davranışlarını ne derecede etkilediğinin özel olarak matematik okuryazarlığı testi kullanılarak belirlenmesi araştırmanın problem durumunu oluşturmaktadır.

\section{Araștırmanın Amacı ve Önemi}

$\mathrm{Bu}$ araştırmada, farklı kavram yanılgısı türleri gözlenen öğrencilerin farklı yanıtlayıcı davranışlarına sahip olup olmadıklarının matematik okuryazarlığı becerileri kapsamında belirlenmesi, en genel ifadeyle kavram yanılgıları ile yanıtlayıcı davranışları birlikte değerlendirildiğinde durumun ne olduğunun ortaya çıkarılması amaçlanmıştır. Bu amaç doğrultusunda aşağıdaki sorulara yanıt aranmıştır:

1. Kavram yanılgısı gözlenen öğrencilerin kavram yanılgısı türlerine göre dağılımları nasıldır?

2. Kavram yanılgıSı gözlenen ve gözlenmeyen öğrencilerin yanıtlayıcı davranışları arasında anlamlı farklılık var mıdır?

3. Kavram yanılgısı gözlenen öğrencilerin yanıtlayıcı davranışları, kavram yanılgısı türlerine göre anlamlı farklılık göstermekte midir?

4. Kavram yanılgısı gözlenen öğrencilerin kavram yanılgısı türlerine ve yanıtlayıcı davranışlarına göre dağılımları, cinsiyetlerine ve bulundukları ilçeye göre anlamlı farklılık göstermekte midir?

Ayrı ayrı kavram yanılgılarını ve yanıtlayıcı davranışlarını belirlemeye çalışan araştırmalarda, çoğunlukla matematik becerileri üzerinden sonuçların elde edildiği görülmektedir. Bu araştırmalarda kavram yanılgıları, geliştirilen kavram yanılgısı testleri ile belirlenmiştir. Bu testlerdeki öğrenci başarılarının da cinsiyet, okunan kitap sayısı, karne notu gibi değişkenlere göre farklılaşma durumu ortaya çıkarılmıştır. Yanıtlayıcı davranışları ise, ilgili madde yanıtlandıktan sonra uygun şekilde işaretlenerek belirlenmiş ve yanıtlayıcı davranışlarının; yaş, cinsiyet, düzeltme formülü verilme durumları, madde güçlüğü gibi değişkenlere göre farklılaşma durumu ortaya çıkarılmıştır. Ancak alanyazında kavram yanılgıları ile yanıtlayıcı davranışlarının bir arada ele alındığı bir çalışmaya rastlanmamıştır. Ayrıca alanyazında kavram yanılgısı ve yanıtlayıcı davranışları ile ilgili ayrı ayrı yapılan araştırmalar açık uçlu ya da çoktan seçmeli testler kullanılarak gerçekleştirilmesine 
karşın üst düzey becerileri ölçen, kavram yanılgılarına dayalı, hem açık uçlu hem de çoktan seçmeli bölümleri olan iki aşamalı bir testin olmayışı, bir eksiklik olarak düşünülmüş ve araştırma kapsamında geliştirilen bu test ile belirtilen eksikliğin giderilmesi hedeflenmiştir.

\section{Yöntem}

$\mathrm{Bu}$ başlık altında araştırmanın modeli, çalışma grubu, veri toplama aracı, verilerin alanlizine yer verilmişsir.

\section{Arastırma Modeli}

$\mathrm{Bu}$ araştırma, kavram yanılgılarıyla yanıtlayıcı davranışları arasındaki ilişkileri incelemesi nedeniyle ilişkisel araştırma modeline örnektir. İlişkisel araştırma modeli, iki ve daha çok değişken arasında ilişki olup olmadığını ve/veya ilişkinin derecesini belirlemeyi amaçlayan bir araştırma modelidir (Fraenkel ve Wallen, 2006).

\section{Evren-Örneklem}

$\mathrm{Bu}$ araştırmanın evrenini, 2016-2017 eğitim-öğretim y1lında Ankara ili genelindeki ortaokul 8. sınıflarda öğrenim gören 63460 öğrenci oluşturmaktadır (Milli Eğitim Bakanlığı-MEB, 2017). Araştırmanın örneklemini, Ankara ilinden seçkisiz olmayan tabakalı örnekleme ile seçilen, üç farklı merkez ilçedeki farklı okullarda öğrenim gören 340 öğrenci oluşturmuştur. Bu öğrenciler Yenimahalle, Çankaya ve Etimesgut ilçelerinde yer alan devlet okullarında öğrenim görmektedir.

Evrenden seçilen bir örneklemin her üyesinin seçilme şansının eşit olmadığı örnekleme yöntemi seçkisiz olmayan örnekleme yöntemi olarak adlandırılmaktadır. Seçkisiz olmayan örnekleme yöntemlerinden tabakalı örnekleme yöntemi, ilgilenilen belli alt grupların özelliklerini göstermek ve bunlar arasında karşılaş̧ırma yapmak amacıyla kullanılır. Bu yöntemde seçkisizlik dikkate alınmaz (Büyüköztürk, KılıçÇakmak, Akgün, Karadeniz ve Demirel, 2008). Bu araştırmanın örneklemi belirlenirken, öncelikle evrende yer alan birey sayısına ulaşılmıştır. MEB'in (2017) internet sitesinde yayınladığı istatistiklere göre 2017 yılında Ankara ilinde 8. sinıfta öğrenim gören 63460 öğrenci bulunmaktadır. Bu büyüklükte bir evreni .05 manidarlık düzeyi ve \pm .05 örnekleme hatası ile en az 380 gözlem biriminden oluşan bir örneklem temsil edebilmektedir (Çıngı, 1990). Uygulamada var olan seçkisiz bir örnekleme ulaşmadaki güçlükler nedeniyle seçkisiz olmayan örnekleme yöntemi tercih edilmiştir. Bu kapsamda ulaşılan gözlem birimi 390 olmasına karşın testte, ikinci aşaması yanıtsız bırakılan madde sayısı, testteki toplam madde sayısının yarısından fazla olan kitapçıklar kayıp veri olarak ele alındığından araştırmanın örneklemini 340 öğrenci oluşturmaktadır. Bu öğrenciler, Ankara ilinin merkez ilçelerinden Çankaya, Yenimahalle ve Etimesgut'ta bulunan ve yine seçkisiz olmayan örnekleme yöntemiyle belirlenen üç farklı okulun 8. sınıflarında öğrenim görmektedir. Örneklemin, bu araştırma kapsamında dikkate alınan bağımsız değişkenlere göre dağılımı Tablo 1'de verilmiştir. 
Tablo 1

Örneklemde Yer Alan Öğrencilerin Cinsiyetlerine Ve Okullarının Bulunduğu İlçelere Göre Dă̆ılımı

\begin{tabular}{llll}
\hline Değişkenler & & f & \% \\
\hline \multirow{3}{*}{ Cinsiyet } & Kadın & 180 & 53 \\
& Erkek & 160 & 47 \\
\cline { 2 - 4 } & Toplam & 340 & 100 \\
\hline \multirow{3}{*}{ İlçe } & Yenimahalle & 126 & 37 \\
& Etimesgut & 100 & 30 \\
& Çankaya & 114 & 33 \\
\cline { 2 - 4 } & Toplam & 340 & 100 \\
\hline
\end{tabular}

Tablo 1'de görüldüğü gibi, cinsiyet için belirtilen frekans ve yüzdelerin birbirine yakın olduğu görülmektedir. Ayrıca, araştırmaya ilçelerden katılan öğrenci sayılarının da birbirine yakın dağılım gösterdiği tablodan gözlenmektedir.

\section{Veri Toplama Aracı}

$\mathrm{Bu}$ çalışmada, tamamı araştırmacı tarafından geliştirilen bir veri toplama aracı (Kişisel Bilgi Formu, İki Aşamalı Tanı Testi ve Yanıtlayıcı Davranışları Formu) kullanılmıştır. Kişisel Bilgi Formu, araștırma kapsamında kullanılacak değişkenlerle birlikte, örneklemin özelliklerinin daha sağlıklı belirlenebilmesi amacıyla gerekli değişkenlerin bir formda ifade edilerek bireylere sunulduğu formdur.

Testin amacının, kavram yanılgılarının belirlenmesinin olduğu saptandıktan sonra öğrencilerin günlük yaşam durumlarına yönelik matematik sorularını çözerken yaşadıkları kavram yanılgıları ve yanıtlayıcı davranışları merak konusu olmuştur. Bu kapsamda araştırmacı tarafından gözlenen, matematik ile ilgili günlük yaşam durumlarıyla bu durumlarda yaşanabilecek, alanyazından ve MEB 5., 6., 7. ve 8. sınıf ortaokul kazanımlarından hareketle belirlenen, kavram yanılgılarını temsil eden kavram yanılgısı kazanımları oluşturulmuştur.

Deneme formunun geliştirilmesi aşamasında, kavram yanılgısı kazanımlarıyla ilgili yazılacak soru sayıları, Graeber ve Johnson'ın (1991) belirttiği kavram yanılgısı türlerine göre ayrılarak belirtke tablosunda ifade edilmiştir. Daha sonra, hazırlanan belirtke tablosu; 8. sınıf matematik dersine giren iki matematik öğretmeni, bir ölçme değerlendirme uzmanı ve bir program geliştirme uzmanından görüş alınarak düzenlenmiştir. Belirtke tablosunun oluşturulmasından sonra belirlenen kazanımlara yönelik istenen kavram yanılgısı türünde madde yazımına başlanmıştır. Maddeler yazılırken günlük yaşam durumları gözlenerek çeşitli çıkarımlar yapılmış ve madde hâline getirilmiştir. Böylece belirlenen 13 kazanımdan 12'sine yönelik; ilk aşaması dört seçenekli çoktan seçmeli, ikinci aşaması ise çözümün/gerekçenin belirtildiği açık uçlu olmak üzere iki aşamalı toplam 60 madde yazılmıştır. Kalan bir kazanıma yönelik madde oluşturulamamıştır. Oluşturulan 60 madde, ikisi hem matematik öğretmeni hem de ölçme ve değerlendirme uzmanı olmak üzere üç ölçme ve 
değerlendirme uzmanı, dört matematik öğretmeni ve iki program geliştirme uzmanına incelenmek üzere verilmiştir. Uzmanlar, gözden geçirdikleri 60 maddenin uygulanmasında yaşanacak zaman sıkıntılarını da belirtmiş ve maddeleri tek - çift ayırma yöntemine göre ayırıp rastgele ikiye ayrılmış gruplara uygulama önerilerini belirtmişlerdir. Bu yöntemle iki aşamalı tanı testinin maddeleri, iki ayrı deneme formuna dağıtılmıştır. Sonuç olarak toplamda 60 sıralanmış denemelik madde, tekçift yöntemiyle ayrılarak aynı kazanımları ölçen, otuzar maddeden oluşan iki ayrı paralel form şeklinde (A ve B) düzenlenmiştir. Deneme uygulaması aşamasında, testin üst düzey davranışları ölçen maddelerden oluştuğu göz önüne alınarak oluşturulan iki aşamalı 60 madde, ilgili okullarda iki ders saati boyunca Ankara ilinin Çankaya, Yenimahalle ve Etimesgut ilçelerinde bulunan 272 öğrenciye uygulanmıştır. Deneme uygulaması sonuçlarının analizi aşamasında, her form için madde ayırt edicilik indeksi ve güçlükleri, çoktan seçmeli bölüm için ayrı, bütünleşik olarak puanlanan yanıt bölümü için ayrı olarak hesaplanmıştır. Bu kapsamda A ve B formlarının bütünleşik güvenirlik değerleri hesaplandığında, Spearman-Brown düzeltme formülüyle hesaplanan Cronbach $\alpha$ değeri .807'dir. $\mathrm{Bu}$ ise, deneme formunun güvenirlik değerinin yüksek olduğunu göstermektedir. Buradan hareketle zor ve yüksek ayırıcılık değerine sahip olan 16 maddelik bir denemelik form oluşturulmuştur. Esas uygulamada, hesaplamalar sonucunda elde edilen 16 maddelik iki aşamalı matematik okuryazarlığı testindeki her maddenin gerekçesi açıklandıktan sonra boş bırakılan kutucuğa, kullanılan ilgili yanıtlayıcı davranışının numarasının yazılması istenmiştir. Bu davranışları belirlemek amacıyla yapılan çalışmalarda kullanılan yanıtlayıcı davranışları formu oluşturulurken konu ile ilgili sınırlı sayıda olan diğer araştırmalardan yararlanılmıştır (Turgut ve Baykul, 2012; Umay,1998). Araştırmacı tarafından geliş̧irilen iki aşamalı tanı testi ile de öğrencilerin matematik okuryazarlığı ile ilgili olası kavram yanılgıları gözlenmiştir. Bu test, Klasik Test Kuramı temelinde test geliştirme aşamaları dikkate alınarak geliştirilmiştir.

Evren-örneklem bölümünde belirtilen gruba bir ders saati süresince 16 maddelik esas form uygulanmış, belirlenen 50 kayıp veri analizlere dahil edilmemiştir. Ayrıca formun son biçimi oluşturulurken; faktör analizinde faktör yükünün .30 ve daha büyük olması, tek faktör altında yer alması ve ayrıca madde toplam korelasyon katsayısının 20 'nin üzerinde olması gerektiği dikkate alınmıştır (Büyüköztürk ve diğ., 2008). Bu bağlamda esas forma ait maddelerin tümünün faktör yük değerleri .30 'dan daha büyük olarak elde edilmiştir.

\section{Verilerin Analizi}

İki aşamalı tanı testinin çoktan seçmeli olan ilk aşamasının doğru, açık uçlu olan ikinci aşamasının yanlış olduğu veya ilk aşamasının doğru, ikinci aşamasının da kısmen doğru olduğu maddelerde kavram yanılgısı olduğu kabul edilerek puanlama yapılmıştır. Birinci alt problemde, kavram yanılgısı gözlenen öğrencilerin kavram yanılgısı türlerine göre dağılımlarını belirlemek amacıyla öğrencilerin her maddeye verdiği yanıtın kavram yanılgısı içerme durumu belirlenmiştir. Daha sonra kavram yanılgisı olma durumunda bu içeriğin hangi kavram yanılgısı türüne ait olduğu 
belirlenmiştir. $\mathrm{Bu}$ amaca yönelik olarak analizler sonucunda sırasıyla bir kavram yanılgısı türüne sahip olanlar, iki kavram yanılgısı türüne sahip olanlar, üç kavram yanılgısı türüne sahip olanlar, dört kavram yanılgısı türüne de sahip olanlar ve hiçbir kavram yanılgısı olmayan öğrencilerin sıklık ve yüzdeleri belirlenmiştir. Graeber ve Johnson'ın (1991) kavram yanılgısı sınıflaması temel alınarak aşırı genelleme, aşırı özelleme, yanlış tercüme ve kısıtlı algılama türü kavram yanılgılarının bireylerde; sadece birinin bulunması, herhangi ikisinin bulunması, herhangi üçünün bulunması ve dördünün birden bulunması durumları incelenmiştir.

İkinci alt problemde, kavram yanılgısı gözlenen ve gözlenmeyen öğrencilerin yanıtlayıcı davranışları arasında anlamı farklılık olma durumlarını belirlemek amacıyla ki-kare analizi yapılmıştır. İki değişken için ki-kare analizi, iki sınıflamalı (kategorik) değişkenin birbirinden bağımsız olup olmadığını test eder. Analiz sonuçlarının anlamlı çıkması, değişkenler arasında bağlantı olduğunu; çıkmaması ise değişkenlerin birbirinden bağımsız olduğunu gösterir (Büyüköztürk, Çokluk ve Köklü, 2014). Bu kapsamda kavram yanılgısı olma durumları "var-yok" olarak kategorik duruma getirilmiş; yanıtlayıcı davranışları da "Sonuca işlem yaparak ulaştım", "Sonuca eleme yaparak ulaştım", "Sonuca rastgele işaretleme yaparak ulaştım" ve "Yanıtsız bıraktım" olmak üzere dört kategori olarak ele alınmıştır.

Üçüncü alt problemde, kavram yanılgısı gözlenen öğrencilerin yanıtlayıcı davranışlarının, kavram yanılgısı türlerine göre manidar farklılık gösterme durumlarını belirlemek amacıyla ki-kare analizi yapılmıştır. Bu araştırma kapsamında kavram yanılgısı türleri dört kategori (aşırı genelleme, aşırı özelleme, yanlış tercüme ve kısıtlı algılama) ve yanıtlayıcı davranışları da dört kategori ("işlem", "eleme", "rastgele" ve "yanıtsız") altında ele alınmıştır.

Dördüncü alt problemde, kavram yanılgısı gözlenen öğrencilerin kavram yanılgısı türlerine ve yanıtlayıcı davranışlarına göre dağılımlarının; cinsiyetlerine ve okullarının bulunduğu ilçeye göre anlamlı farklılık gösterme durumlarını belirlemek amacıyla ki-kare analizi yapılmıştır. Analizler SPSS 21 paket programı ile yürütülmüştür.

\section{Bulgular}

$\mathrm{Bu}$ araştırmada birinci alt problem, kavram yanılgısı gözlenen öğrencilerin kavram yanılgısı türlerine göre dağılımlarının nasıl olduğudur. Bu amaçla yapılan analizler sonucunda, sırasıyla bir kavram yanılgısı türüne sahip olanlar, iki kavram yanılgısı türüne sahip olanlar, üç kavram yanılgısı türüne sahip olanlar, dört kavram yanılgısı türüne de sahip olanlar ve hiçbir kavram yanılgısı olmayan öğrenci sayıları Tablo 2'de verilmiştir. 
Tablo 2

Kavram Yanılgısı Gözlenen/Gözlenmeyen Öğrenci Sayılarının Kavram Yanılgısı Türlerine Göre Dăğlımları

\begin{tabular}{|c|c|c|c|}
\hline Kavram Yanılgısı Türleri & $\mathbf{N}$ & \%(Toplam) & \%(Yanılgı İçinde) \\
\hline Aşırı Genelleme & 0 & 0 & 0 \\
\hline Aşırı Özelleme & 0 & 0 & 0 \\
\hline Yanlış Tercüme & 0 & 0 & 0 \\
\hline Kisitlı Algilama & 0 & 0 & 0 \\
\hline Aşırı Genelleme ve Aşırı Özelleme & 0 & 0 & 0 \\
\hline Aşırı Genelleme ve Yanlış Tercüme & 0 & 0 & 0 \\
\hline Aşırı Genelleme ve Kısıtlı Algılama & 32 & 9.4 & 9.7 \\
\hline Aşırı Özelleme ve Yanlış Tercüme & 0 & 0 & 0 \\
\hline Aşırı Özelleme ve Kısıtlı Algılama & 4 & 1.3 & 1.4 \\
\hline Yanlış Tercüme ve Kısıtlı Algılama & 11 & 3.2 & 3.3 \\
\hline Aşırı Genelleme, Aşırı Özelleme ve Yanlış Tercüme & 1 & 0.3 & 0.3 \\
\hline Aşırı Genelleme, Yanlış Tercüme ve Kısıtlı Algılama & 136 & 40.0 & 41.5 \\
\hline Aşırı Genelleme, Aşırı Özelleme ve Kısıtlı Algılama & 13 & 3.9 & 4.1 \\
\hline Aşırı Özelleme, Yanlış Tercüme ve Kısıtlı Algılama & 6 & 1.7 & 1.8 \\
\hline Tüm Türler & 123 & 36.1 & 37.2 \\
\hline Hiçbir Tür & 14 & 4.1 & 4.3 \\
\hline Toplam & 340 & 100 & \\
\hline
\end{tabular}

Tablo 2 incelendiğinde, genel olarak 340 öğrenciden 326'sında kavram yanılgısı gözlenmiş, 14'ünde gözlenmemiştir. Bu 326 öğrenciden hiçbirinin tek bir kavram yanılgısı türüne sahip olmadığı görülmektedir. Ayrıca aşırı genelleme ile aşırı özelleme, aşırı genelleme ile yanlış tercüme ve aşırı özelleme ile yanlış tercüme türü kavram yanılgılarının ikisine birden sahip olan öğrenci de bulunmamaktadır. Aşırı genelleme ile birlikte kısıtlı algılama kavram yanılgısını 32 öğrencinin (\% 9.4) yaşadığı görülmektedir. Aşırı özelleme ile birlikte kısıtlı algılama kavram yanılgısını ise dört öğrencinin (\% 1.3) yaşadığı, yanlış tercüme ile birlikte kısıtlı algılama kavram yanılgısını da 11 öğrencinin (\% 3.2) yaşadığı belirlenmiştir. Bu durum, öğrencilerin çoğunlukla ikiden fazla kavram yanılgısına sahip olduklarını göstermektedir.

Aşırı genelleme, aşırı özelleme ile birlikte yanlış tercüme kavram yanılgısı türüne sahip bir öğrencinin (\% 0.3); aşırı genelleme, yanlış tercüme ile birlikte kısıtlı algılama kavram yanılgısı türüne sahip 136 öğrencinin (\% 40); aşırı genelleme, aşırı özelleme ile birlikte kısıtlı algılama kavram yanılgısı türüne sahip13 öğrencinin (\% 3.9); aşırı özelleme, yanlış tercüme ile birlikte kısıtlı algılama kavram yanılgısı türüne sahip ise altı öğrencinin (\% 1.7) bulunduğu görülmektedir. Bu durum öğrencilerin en çok; aşırı genelleme, yanlış tercüme ile birlikte kısıtlı algılama kavram yanılgısı türünde yanılgılarının olduğunu göstermektedir. Tüm kavram yanılgısı türlerine sahip olan öğrenci sayısının ise 123 (\% 36.1) olduğu görülmektedir. Öğrencilerin 14’ünün (\% 4.1) de hiçbir kavram yanılgısına sahip olmadığı belirlenmiştir. Çizelge genel olarak incelendiğinde ise, 47 öğrencinin (\% 13.9) sadece iki tür kavram yanılgısını yaşadığı 156 öğrencinin (\% 45.9) üç kavram yanılgısına aynı anda sahip olduğu ve 
123 öğrencinin (\% 36.1) tüm kavram yanılgılarına sahip olduğu belirlenmiştir. Buradan hareketle öğrencilerin yaklaşık \% 82'sinin üç veya daha fazla sayıda kavram yanılgısı türüne birden sahip olduğu görülmektedir. Bu durum örneklemin farklı ilçelerdeki okullardan olduğu düşünüldüğünde, her okulun benzer yanılgılara sahip olduğunu ortaya çıkarmaktadır.

İki aşamalı tanı testinin, kavram yanılgılarını belirlemek amacıyla hazırlandığ göz önüne alındığında, kavram yanılgısına sahip olduğu belirlenen öğrencilerin kararını alırken ilgili yanılgı türündeki madde sayılarının en az yarısında 1-1 ya da 10 puan alma durumu gözetilmiştir. Bu bağlamda aşırı genelleme, aşırı özelleme, yanlış tercüme ve kısıtlı algılama kavram yanılgısı türleri için sırasıyla 3 ve üzeri, 1 ve üzeri, 3 ve üzeri, 2 ve üzeri maddede kavram yanılgısı gözlenmiş olması dikkate alınmıştır. Bu ölçütler birlikte ele alındığında ise 36 öğrencinin (\% 11) beklenen kavram yanılgısı türlerinin tümünü yaşadığı belirlenmiştir. Bu sonuç, Baki ve Güç’ün (2014), dokuzuncu sınıf öğrencilerinin devirli ondalık gösterimlerle ilgili kavram yanılgılarını belirledikleri çalışmanın sonuçlarıyla benzerlik göstermektedir. Buradan hareketle öğrencilerin kavram öğrenmelerinin beklenen düzeyde olmadığı söylenebilir.

İkinci araştırma sorusuna yönelik olarak, kavram yanılgısı gözlenen ve gözlenmeyen öğrencilerin yanıtlayıcı davranışları arasında anlamlı farklılık olup olmadığını belirlemek üzere yapılan ki-kare analizi sonuçlarında kavram yanılgısı olan öğrencilerin, 16 maddenin 12'sinde en çok gösterdikleri eleme davranışı, en az gösterdikleri ise yanıtsız bırakma davranışıdır. Kavram yanılgısı görülmeyen öğrencilerin, 16 maddenin dokuzunda en çok gösterdikleri eleme davranışı, en az gösterdikleri ise rastgele işaretleme davranışıdır. Buradan hareketle kavram yanılgısı olanların yanıtsız bırakma davranışını göstermediği, kavram yanılgısı olmayanların ise bu davranış türünü daha çok gösterdiği belirtilebilir. Kavram yanılgısının, verilen yanıttan emin olma durumunda ortaya çıktığı göz önüne alındığında, bu durumun, sonuçları destekler nitelikte olduğu söylenebilir. Ki kare bağımlılık testi sonuçlarına bakıldığında ise tüm değerlerin anlamlı olduğu görülmektedir. Buna göre her bir maddede öğrencilerin yanıtlayıcı davranışları, bu madde kapsamında kavram yanılgısı olma ve olmama durumlarına göre farklılaşmaktadır.

Genel olarak, kavram yanılgısı olan öğrencilerin çoğunlukla eleme davranışını kullandıkları, kavram yanılgısı olmayan öğrencilerin ise işlem yapma ve eleme davranışlarını kullandıkları görülmektedir. Ayrıca kavram yanılgısı olmayan öğrencilerin, madde güçlüğü yüksek olan maddeleri rastgele işaretleme davranışlarının, kavram yanılgısı olan öğrencilere göre çok daha fazla olduğu dikkati çekmektedir. Bu durum kavram yanılgısının tanımı ile birlikte ele alındığında, kavram yanılgısı olan öğrencilerin rastgele işaretlemeyi daha az yapmalarının tutarlı bir sonuç olduğunu gösterebilir. $\mathrm{Bu}$ ise, yanılgıya sahip olmayan öğrencilerin bilgilerinden emin olmadıkları durumda eleme yapmadan rastgele işaretleme davranışını gösterdiklerini ortaya çıkarmaktadır. Bu durum, Kadığlu (2002) ve Pehlivan ve Kutlu'nun (2014) bulgularıyla örtüşmektedir. 
Üçüncü araştırma sorusuna yönelik olarak, kavram yanılgısı türlerine göre tüm öğrencilerin gösterdiği yanıtlayıcı davranışları ele alındığında ise; aşırı genelleme, yanlış tercüme ve kısıtlı algılama kavram yanılgısı türlerinde en çok eleme davranışının, aşırı özelleme kavram yanılgısı türünde ise en çok rastgele işaretleme davranışının gösterildiği belirlenmiştir. Ayrıca aşırı genelleme, yanlış tercüme ve kısıtlı algılama kavram yanılgısı türlerinde en az yanıtsız bırakma davranışının; aşırı özelleme kavram yanılgısı türünde ise en az işlem yapma davranışının gösterildiği belirlenmiştir. Bu sonuçlardan hareketle aşırı özelleme kavram yanılgısı türüne ait maddelerin güçlükleri incelendiğinde, bu maddelerin öğrencilere çok zor geldiği görülmektedir. Madde bazlı kavram yanılgısı türleri ele alındığında, yukarıda elde edilen sonuç, her yanıtlayıcı davranışında kavram yanılgısı olanların olmayanlardan daha az olduğu şeklinde belirtilebilir.

Kavram yanılgısı gözlenen öğrencilerin yanıtlayıcı davranışlarının kavram yanılgısı türlerine göre farklılık gösterme durumları incelendiğinde, dört farklı kavram yanılgısı türüne ait maddelerde, kavram yanılgısı belirlenen öğrencilerin belirttikleri yanıtlayıcı davranışlarına göre dağılımı verilmiştir. Her madde, bir tane kavram yanılgısı türüne ait olduğundan ki kare değerleri madde bazlı olarak, kavram yanılgısı türünün olup olmaması durumuna göre hesaplanmıştır. Bu bağlamda tüm ki kare değerleri, kritik değerden $\left(\chi^{2}=7.81\right)$ büyük ve p değerleri $.05^{\prime}$ ten küçük olduğu için yanıtlayıcı davranışları ile kavram yanılgısı türleri arasında anlamlı bir ilişki olduğu görülmektedir. Buna göre öğrencilerin kavram yanılgısı türlerine ait maddelerde kavram yanılgısı olma ve olmama durumlarının yanıtlayıcı davranışlarına göre birbirinden farklılaştığı belirtilebilir.

Ayrıca üçüncü araştırma sorusu kapsamında, kavram yanılgısı olan ve sonuca işlem yaparak ulaşan öğrenciler en çok kısıtllı algılamaya ait maddelere işlem yaparak yanıt vermiş̧tir. $\mathrm{Bu}$ ise, maddelerin işlem ile kolayca yapplabileceğinden, işlem yaparak sonuca ulaşan ancak kavram yanılgısı olduğu belirlenen öğrencilerin kısıtlı algılamaya ait maddelerde, diğer maddelere göre daha öz güvenli davrandığını ve kendi bilişsel süreçlerinde oluşturdukları kavramlardan, diğer maddelere göre daha emin olabileceklerini düşündürmektedir.

Kavram yanılgısı olan ve sonuca eleme yaparak ulaşan öğrenciler en çok kısıtlı algılamaya ait maddelere eleme ile yanıt vermiş̧ir. Bu ise, maddeler grafik oluşturma ve grafiğe ulaşma ile ilgili olduğundan, eleme yaparak sonuca ulaşan ancak kavram yanılgısı olduğu belirlenen öğrencilerin kısıtlı algılamaya ait maddelerde, diğer maddelere göre daha öz güvenli davrandığını ve kendi bilişsel süreçlerinde oluşturdukları kavramlardan, diğer maddelere göre daha emin olduklarını göstermektedir.

Kavram yanılgısı olan ve sonuca rastgele işaretleme yaparak ulaşan öğrenciler en çok aşırı özellemeye ait maddelere yanıt vermiştir. Bu ise, kavram yanılgısı olduğu belirlenen öğrencilerin aşırı özellemeye ait maddelerde örüntü oluşturulmasının istenmesinden ve bu soruların uzun olmasından dolayı rastgele işaretleme yapıldığı düşüncesini ortaya çıkarmaktadır. 
Kavram yanılgısı olan ve ilgili maddeleri yanıtsız bırakan öğrenciler en çok aşırı özellemeye ait maddelere yanıt vermiştir. $\mathrm{Bu}$ ise, maddeleri yanıtsız bırakan ve kavram yanılgısı olduğu belirlenen öğrencilerin aşırı özellemeye ait maddelerde örüntü oluşturulmasının istenmesinden ve bu soruların uzun olmasından dolayı yanıtsız bırakma davranışının gösterildiği düşüncesini oluşturmaktadır.

İki aşamalı tanı testinde öncelikle kavram yanılgılarının cinsiyet değişkeni açısından farklılaşıp farklılaşmadığını belirlemek amacıyla gerçekleştirilen ki kare analizi sonuçları incelendiğinde, cinsiyeti erkek olan öğrencilerin 16 maddenin 12 'sinde en çok aldıkları bütünleşik puan 0 , en az aldıkları bütünleşik puan ise 2, 3 ve 4'tür. Cinsiyeti kadın olan öğrencilerin 16 maddenin 11'inde en çok aldıkları bütünleşik puan 0, en az aldıkları bütünleşik puan ise 2, 3 ve 4 'tür. Ayrıca kavram yanılgılarını gerçekleştirme açısından incelendiğinde, 59. madde haricinde görülen ki kare değerleri, kritik değerden $\left(\chi^{2}=11.070\right)$ küçük ve p değerleri .05'ten büyük olduğu için sahip olunan kavram yanılgıları, genel olarak cinsiyete göre anlamlı bir fark göstermemektedir.

İki aşamalı tanı testini alan öğrencilerin yanıtlayıcı davranışlarının cinsiyete göre dağılımı incelendiğinde cinsiyeti erkek ve kadın olan öğrencilerin iki aşamalı tanı testindeki maddelere gösterdikleri yanıtlayıcı davranışları, "Sonuca işlem yaparak ulaştım", "Sonuca eleme yaparak ulaştım", "Rastgele işaretleme yaptım", "Yanıtsız bıraktım" başlıkları altında toplanarak maddelere göre sınıflandırılmıştır.

Cinsiyeti erkek olan öğrencilerin 16 maddenin 12'sinde en çok gösterdikleri yanıtlayıcı davranışı eleme, en az gösterdikleri yanıtlayıcı davranışı ise yanıtsız bırakmadır. Cinsiyeti kadın olan öğrencilerin 16 maddenin 12 'sinde en çok gösterdikleri yanıtlayıcı davranışı eleme, en az gösterdikleri yanıtlayıcı davranışı ise yanıtsız bırakmadır. Ayrıca çizelgede görülen tüm ki kare değerleri, kritik değerden $\left(\chi^{2}=7.81\right)$ küçük ve p değerleri .05'ten büyük olduğu için yanıtlayıcı davranışları ile cinsiyet arasında anlamlı bir ilişki bulunamadığı görülmektedir. Diğer bir deyişle ile öğrencilerin yanıtlayıcı davranışlarının, kadın veya erkek olma durumlarına göre birbirinden farklılaşmadığ

İki aşamalı tanı testini alan öğrencilerin yanıtlayıcı davranışlarının bulundukları ilçeye göre dağılımı incelendiğinde, hem Çankaya hem Yenimahalle hem de Etimesgut ilçelerinde öğrenim gören öğrencilerin 16 maddenin 12'sinde en çok gösterdikleri yanıtlayıcı davranışı eleme, en az gösterdikleri yanıtlayıcı davranışı ise yanıtsız bırakmadır. M12 haricinde görülen tüm ki kare değerleri, kritik değerden $\left(\chi^{2}\right.$ = 12.592) küçük ve p değerleri .05'ten büyük olduğu için yanıtlayıcı davranıșları ile okulların bulunduğu ilçeler arasında anlamlı bir ilişki bulunamadığı görülmektedir. Diğer bir deyişle öğrencilerin yanıtlayıcı davranışlarının, bulundukları ilçeye göre birbirinden farklılaşmadığı belirtilebilir. Buradan hareketle sosyoekonomik düzeyi düşük ve yüksek olan ilçelerde yanıtlayıcı davranışlarının benzer dağılım gösterdiği söylenebilir. 
İki aşamalı tanı testini alan öğrencilerin yaşadığı kavram yanılgısı türlerinin cinsiyete göre dağılımı incelendiğinde, erkek öğrencilerin genel olarak 16 maddenin 14'ünde çoğunlukla kavram yanılgısı göstermedikleri, en az gösterdikleri kavram yanılgısı türünün ise aşırı özelleme olduğu görülmektedir. Kız öğrencilerin ise, genel olarak 16 maddenin 13'ünde çoğunlukla kavram yanılgısı göstermedikleri, en az gösterdikleri kavram yanılgısı türünün ise aşırı özelleme olduğu görülmektedir.

Maddeler bazında aşırı genelleme türü kavram yanılgısına sahip olan erkek öğrenciler 325 kişi (\% 12.7), kadın öğrenciler 369 kişi (\% 12.8); aşırı özelleme türü kavram yanılgısına sahip olan erkek öğrenciler 79 kişi (\% 3.1), kadın öğrenciler 84 kişi (\% 3); yanlış tercüme türü kavram yanılgısına sahip olan erkek öğrenciler 284 kişi (\% 11.1), kadın öğrenciler 296 kişi (\% 10.2); kısıtlı algılama türü kavram yanılgısına sahip olan erkek öğrenciler 210 kişi (\% 8.2), kadın öğrenciler 201 kişi (\% 7) olarak belirlenmiştir. Ayrıca 59. madde haricinde tüm ki kare değerleri, kritik değerden $\left(\chi^{2}=7.81\right)$ küçük ve $p$ değerleri $.05^{\prime}$ ten büyük olduğu için kavram yanılgısı türü ile cinsiyet arasında anlamlı bir ilişkinin bulunmadığı görülmektedir. Buna göre öğrencilerin kavram yanılgısı türlerini gerçekleştirme durumunun, kadın veya erkek olma durumlarına göre birbirinden farklılaşmadığı belirtilebilir.

İki aşamalı tanı testini alan öğrencilerin yaşadığı kavram yanılgısı türlerinin öğrencilerin okullarının bulundukları ilçeye göre dağılımı incelendiğinde, okulları Çankaya'da ve Yenimahalle'de bulunan öğrencilerin genel olarak 16 maddenin 12 'sinde çoğunlukla kavram yanılgısı göstermedikleri, en az gösterdikleri kavram yanılgısı türünün ise aşırı özelleme olduğu görülmektedir. Okulları Etimesgut'ta bulunan öğrencilerin ise, genel olarak 16 maddenin 14'ünde çoğunlukla kavram yanılgısı göstermedikleri, en az gösterdikleri kavram yanılgısı türünün ise aşırı özelleme olduğu görülmektedir. Bu bağlamda öğrencilerin kavram yanılgısı türünü gösterme durumu ile okulların bulunduğu ilçeler arasında genel olarak anlamlı bir ilişkinin bulunmadığı söylenebilir. Buradan hareketle sosyoekonomik düzeyi düşük ve yüksek olan ilçelerde kavram yanılgısı türlerinin benzer dağılım gösterdiği anlaşılmaktadır.

\section{Tartışma, Sonuç ve Öneriler}

Elde edilen bulgulara göre, öğrencilerde iki ve daha fazla sayıda kavram yanılgısı türünün birlikte görüldüğü belirlenmiş̧tir. Öğrencilerin çoğunlukla aşırı genelleme, yanlış tercüme ve kısitlı algılama kavram yanılgısı türlerinde yanılgılarının olduğu, aşırı özelleme türündeki yanılgılarının ise göreli olarak daha az olduğu görülmüştür. Bu durum ise, öğrencilerin yanılgılarının daha çok tümevarma ile ilgili olduğunu ortaya çıkarmaktadır. Ayrıca kavram yanılgısı olma ve olmama durumuna göre yanıtlayıcı davranışlarının farklılaştı̆̆ı, kavram yanılgısı olan ve olmayan öğrencilerin çoğunlukla eleme davranışını gösterdiği, fakat kavram yanılgısı olmayan öğrencilerin en az olarak rastgele yanıtlama davranışı gösterirken kavram yanılgısı olan öğrencilerin en az olarak yanıtsız bırakma davranışını gösterdiği belirlenmiştir. Yanıtlayıcı davranışlarının kavram yanılgısı türlerine göre dağılımına genel olarak bakıldığında ise, her dört kavram yanılgısı türüne ait maddelerde en çok 
işaretlenen yanıtlayıcı davranışı türünün eleme yaparak sonuca ulaşma olduğu görülmektedir. Madde güçlüklerinin yüksek olduğu ve çeldiricilerin kavram yanılgılarına göre hazırlandığı göz önüne alındığında, öğrencilerin en çok eleme yoluyla maddeleri yanıtlamasının beklenen bir sonuç olduğu belirtilebilir. Bu sonuç, Pehlivan ve Kutlu'nun (2014) Türkçe test maddelerinde yanıtlayıcı davranışlarını inceledikleri çalışmalarının bulgularıyla örtüşmektedir. Ancak Koçak (2013) ve Tokat'ın (2006) bulgularıyla örtüşmemektedir. Bu durumun, ilgili çalışmaların örneklemlerinin, bu çalışmanın örnekleminden daha az olmasından kaynaklanabileceği düşünülmektedir. Ayrıca kavram yanılgısı olan öğrencilerin bildiklerine emin olduğunda kesinlikle işaretleme yaptıkları dikkate alındığında bu durum kavram yanılgısı tanımı ile örtüşmektedir.

Kavram yanılgısı türlerine göre yanıtlayıcı davranışları ele alındığında; aşırı özelleme kavram yanılgısında en çok rastgele işaretleme davranışının kullanıldığı; aşırı genelleme, yanlış tercüme ve kısıtlı algılama türlerinde ise en çok eleme davranışının kullanıldığı belirlenmiştir. Aşırı özelleme türüne ait maddeler incelendiğinde, madde güçlüklerinin yüksek olduğu, buna bağlı olarak aşırı özelleme türünde rastgele işaretleme yapılması durumunun önemli bir sonuç olduğu düşünülmektedir. Kavram yanılgısı olan öğrencilerin kavram yanılgısı türlerine göre yanıtlayıcı davranışları ele alındığında ise, kavram yanılgısı türlerinin yanıtlayıcı davranışlarına göre anlamlı düzeyde farklılaştı̆̆ ve kavram yanılgısı olan öğrencilerin işlem ya da eleme yaparak sonuca ulaşması beklendiğinden, işlem yaparak sonuca ulaşan en çok öğrencinin kısıtlı algılama kavram yanılgısı türüne, eleme yaparak sonuca ulaşan en çok öğrencinin de aynı kavram yanılgısı türüne sahip olduğu saptanmıştır.

Sahip olunan kavram yanılgıları, genel olarak cinsiyete göre anlamlı bir fark göstermemektedir. $\mathrm{Bu}$ yönüyle araştırma sonucu, Yenilmez ve Yaşa (2008) ile Kaygusuz'un (2011) araştırma sonuçlarıyla örtüşmekle beraber Ubuz (1999) ile Ayyıldız'ın (2010) araştırma sonuçlarıyla örtüşmemektedir. 10 ve 11. sınıfların temel geometri konularından olan Açılar ile ilgili kavram yanılgılarını inceleyen Ubuz (1999), 67 öğrenciyle gerçekleştirdiği bu çalışmada, Türk toplumunda kadınların daha girişken olmasından dolayı kavram yanılgılarını gerçekleştirme olasılıklarının erkeklere göre fazla olduğu savından hareketle erkekler ile kadınlar arasında erkekler lehine fark olduğunu belirtmiştir. Ancak cinsiyete bağlı olarak söz edilen değişkenlerle (girişkenlik, toplumsal rol vb.) kavram yanılgıları arasındaki ilişki bilimsel olarak temellendirilmemiştir. Ayyıldız (2010) ise, 78 öğrenciyle gerçekleştirdiği, 6. sınıf Geometriye Merhaba ünitesine ilişkin kavram yanılgılarını gidermede öğrenme günlüklerinin etkisini incelemiş ve bu deneysel çalışmada deney grubu kız ve erkek öğrencilerinin son test toplam puanları arasındaki farkın kızlar lehine anlamlı olduğunu belirtmiştir. Her iki çalışma ile bu çalışmanın sonuçlarındaki farklılığın kaynaklarından birinin, örneklem büyüklüğü olabileceği düşünülmektedir.

Benzer şekilde yanıtlayıcı davranışlarının da cinsiyetlere göre anlamlı düzeyde farklılaşmadığ 1 sonucu elde edilmiştir. Bu kapsamda hem erkeklerin hem de 
kadınların en çok gösterdiği yanıtlayıcı davranışının eleyerek sonuca ulaşma, en az gösterdiği yanıtlayıcı davranışının ise yanıtsız bırakma olduğu görülmüştür. Eleyerek yanıtlama davranışlarının çok olması, seçenekler arasında kalarak tahmin etme davranışının çok olması anlamına gelmektedir. Reys ve diğ. (1991) çalışmalarında, 8 . sınıf öğrencilerinde cinsiyete göre tahmin becerilerinde farklılık görülmediği ortaya çıkmıştır. Bu sonuç, araştırmayı destekler niteliktedir.

Alanyazın incelendiğinde, kavram yanılgısı türleri ile ilgili bir çalı̧̧maya rastlanmamakla beraber Yenilmez ve Yaşa (2008), doğru, doğru parçası ve ışın ile ilgili öğrencilerin kavram yanılgılarının cinsiyete göre farklılık göstermediği; Kaygusuz (2011) da benzer biçimde öğrencilerin çember ile ilgili kavram yanılgılarının cinsiyete göre farklılık göstermediği sonucunu elde etmiştir. Sonuçların, bu araştırmanın sonuçları ile örtüştüğü görülmektedir. Diğer yandan Ubuz (1999), temel geometri ile ilgili kavram yanılgılarında cinsiyete göre erkekler lehine bir fark elde etmiş buna karşın, kızların başarısının daha yüksek olduğunu belirtmiştir. Ayrıca Ayyıldız (2010), kız öğrencilerin erkek öğrencilere göre geometri ile ilgili daha az kavram yanılgısı yaşadıklarını dile getirmiştir. Sonuçların, bu araştırmanın sonuçları ile örtüşmediği görülmektedir. Kavram yanılgısı türleri ile ilgili genel olarak, hem erkeklerin hem de kadınların en çok yaşadıkları kavram yanılgısı türünün aşırı genelleme, en az yaşadıkları kavram yanılgısı türünün ise aşırı özelleme olduğu görülmektedir. Yanıtlayıcı davranışlarının, öğrencilerin okullarının bulunduğu ilçeye göre dağılımlarına bakıldığında ise, anlamlı bir ilişkinin gözlenemediği belirtilebilir.

$\mathrm{Bu}$ araştırmanın bulgularından hareketle kavram yanılgıları ve yanıtlayıcı davranışları arasındaki ilişki, bu konularla ilgili araştırma yapacak diğer araştırmacılar tarafindan dikkate alınmalıdır. Kavram yanılgılarına bakarak yanıtlayıcı davranışlarının düzeyinin ve yanıtlayıcı davranışlarının ele alınmasıyla da kavram yanılgılarının türünün anlaşılma olasılığı bulunmaktadır. Kavram yanılgısı olan öğrencilerin genellikle şans etkenini kullanarak eleme davranışı gösterdiği göz önüne alındığında ise, gösterdikleri yanıtlayıcı davranışına göre uygulanacak test türüne karar verilebilir. Uygun test türüyle kavram yanılgıları daha etkili şekilde belirlenebilir. Öğretim etkinliklerine geçilmeden önce öğrencilerin ön koşul öğrenme düzeyleri ile kavram yanılgıları ve hangi kavram yanılgısı türlerinin görüldüğü belirlenebilir. Bunun için yapılacak çalışmalar, öğrencinin zihinsel süreçlerinin daha sağlıklı bir şekilde belirlenerek gerekli önlemlerin alınması açısından etkili olabilir. Ayrıca yapılacak diğer araştırmalarda kavram yanılgılarının gözlenmesinde, kullanım zorluklarına karşın üç ve dört aşamalı testler uygulanabilir.

$\mathrm{Bu}$ araştırma, Ankara ilinin üç ilçesinde yer alan devlet okullarındaki 8. sınıf öğrencilerinin katılımıyla gerçekleşmiştir. Benzer bir araştırma, kavram yanılgılarına yönelik eğitim süreçlerinin farklılaşma durumunu belirlemek bakımından özel ve devlet okullarında yapılarak sonuçlar karşılaştırılabilir. Bir başka öneri olarak, bu araştırmanın ortaokul 8. sınıf öğrencileri ile yürütüldüğü göz önüne alındığında, benzer araştırmaların ortaöğretim ve lisans düzeylerinde de yürütülmesinin alana katkı sağlayacağı düşünülmektedir. Bu araştırma kapsamında kavram yanılgıları ile 
yanıtlayıcı davranışları arasındaki ilişki irdelenmiştir. Kavram yanılgılarıyla ilişsili olabilecek diğer değişkenler (başarı, dikkat, tutum vb.) dikkate alınarak yeni çalışmalar yapılabilir.

\section{Kaynakça}

Akdemir, E. (2005). İlköğretim ikinci kademe yedinci slnı ögrencilerinin katı ve sıvıların basıncı konusunda sahip oldukları kavram yanılgıları (Yayımlanmamış yüksek lisans tezi). Balıkesir Üniversitesi Fen Bilimleri Enstitüsü, Balıkesir.

Atasoy, Ş. ve Akdeniz, A. R. (2007). Newton'un hareket kanunları konusunda kavram yanılgılarını belirlemeye yönelik bir testin geliştirilmesi ve uygulanması. Türk Fen Eğitimi Dergisi, 4(1), 45-59. https://docplayer.biz.tr/51641616-Newton-unhareket-kanunlari-konusunda-kavram-yanilgilarini-belirlemeye-yonelik-birtestin-gelistirilmesi-ve-uygulanmasi.html adresinden edinilmiştir.

Ayyıldız, N. (2010). 6. sinıf matematik dersi geometriye merhaba ünitesine iliş̧kin kavram yanlgılarının giderilmesinde ögrenme günlüklerinin etkisinin incelenmesi (Yayımlanmamış yüksek lisans tezi). Yıldız Teknik Üniversitesi Sosyal Bilimler Enstitüsü, İstanbul.

Baki, A. ve Güç, F. A. (2014). Dokuzuncu sınıf öğrencilerinin devirli ondalık gösterimle ilgili kavram yanılgıları. Turkish Journal of Computer and Mathematics Education, 5(2), 176-206. https://dergipark.org.tr/en/download/article-file/201371 adresinden edinilmiştir.

Büyüköztürk, Ş., Çokluk, Ö. ve Köklü, N. (2014). Sosyal bilimler için istatistik. Ankara: Pegem Akademi Yayınları.

Büyüköztürk, S., Kılıç-Çakmak, E., Akgün, O. E., Karadeniz, S. ve Demirel, F. (2008). Bilimsel araştırma yöntemleri. Ankara: Pegem Akademi Yayınları.

Çakır, M. ve Aldemir, B. (2011). İki aşamalı genetik kavramlar tanı testi geliştirme ve geçerlik çalışması. Mustafa Kemal Üniversitesi Sosyal Bilimler Enstitüsü Dergisi, 8(16), 335-353. https://toad.halileksi.net/sites/default/files/pdf/ikiasamali-tani-testi-toad.pdf adresinden edinilmiştir.

Çetin, O. ve Günay, Y. (2010). Fen öğretiminde yapılandırmacıllk kuramının öğrencilerin başarılarına ve bilgiyi yapılandırmalarına olan etkisi. Eğitim ve Bilim, 32(146), 24-38. http://egitimvebilim.ted.org.tr/index.php/EB/article/view/725/143 adresinden edinilmiştir.

Chandrasegaran, A., Treagust, D. F., and Mocerino, M. (2007). The development of a two-tier multiple-choice diagnostic instrument for evaluating secondary school students' ability to describe and explain chemical reactions using multiple levels of representation. Chemistry Education Research and Practice, 8(3), 293-307. doi: 10.1039/B7RP90006F 
Çıngı, H. (1990). Örnekleme kuramı. Ankara: Hacettepe Üniversitesi Fen Fakültesi Yayınları.

Coştu, B., Ayas, A. ve Ünal, S. (2007). Kavram yanılgıları ve olası nedenleri: Kaynama kavramı. Kastamonu Ë̌itim Dergisi, 15(1), 123-136. https://www.researchgate.net/publication/284631537_Kavram_yanilgilari_ve_ olasi_nedenleri_Kaynama_kavrami adresinden edinilmiştir.

Delgado, A. R., and Prieto, G. (2004). Cognitive mediators and sex-related differences in mathematics. Intelligence, 32(1), 25-32.

Demirtaşl1, N. (2010). Üst düzey düşünme becerilerinin ölçülmesinde gündelik yaşam unsuru. Cito Eğitim: Kuram ve Uygulama, 7, 9-26.

Fisher, K. M. (1985). A misconception in biology: Amino acids and translation. Journal of Research in Science Teaching, 22(1), 53-62.

Fraenkel, J., and Wallen, N. (2006). How to design and evaluate research in education. New York, NY: Mc Graw Hill Publication.

Garnett, P. J., and Treagust, D. F. (1992). Conceptual difficulties experienced by senior high school students of electrochemistry: Electrochemical (galvanic) and electrolytic cells. Journal of Research in Science Teaching, 29(10), 1079-1099.

Graeber, A., and Johnson, M. (1991). Insights into secondary school students' understanding of mathematics. College Park, University of Maryland, MD.

Gürdal, H. (2008). İlköğretim 5. Sinıf fen ve teknoloji dersi, maddenin değişimi ve tanınması ünitesinde ögrencilerde oluşan kavram yanılgılarının tespitinde iki aşamalı soruların kullanılabilirliği üzerine bir araștırma (Yayımlanmamış yüksek lisans tezi). Celal Bayar Üniversitesi Sosyal Bilimler Enstitüsü, Manisa.

Hammer, D. (1996). Misconceptions or p-prims: How may alternative perspectives of cognitive structure influence instructional perceptions and intentions. The Journal of the Learning Sciences, 5(2), 97-127.

Haslam, F., and Treagust, D. F. (1987). Diagnosing secondary students' misconceptions of photosynthesis and respiration in plants using a two-tier multiple choice instrument. Journal of Biological Education, 21(3), 203-211.

Kadıŏlu, B. (2002). Çoktan seçmeli testlerde test maddelerini cevaplama davranışlarının, madde ve ögrenci özelliklerine göre nasıl bir değişim gösterdiğinin incelenmesi (Yayımlanmamış yüksek lisans tezi), Hacettepe Üniversitesi Sosyal Bilimler Enstitüsü, Ankara.

Karataş, F. Ö., Köse, A. G. S. ve Coştu, A. G. B. (2003). Öğrenci yanılgılarını ve anlama düzeylerini belirlemede kullanılan iki aşamalı testler. Pamukkale Üniversitesi Eğitim Fakültesi Dergisi, 13(13), 54-69. 
Kaygusuz, Ç. (2011). İlköğretim beşinci sınıf matematik dersi programında yer alan "çember alt ögrenme” alanına ait kavram yanılgılarının belirlenmesi (Yayımlanmış yüksek lisans tezi). Gazi Üniversitesi Eğitim Bilimleri Enstitüsü, Ankara.

Kenan, O. ve Özmen, H. (2014). Maddenin tanecikli yapısına yönelik iki aşamalı çoktan seçmeli bir testin geliştirilmesi ve uygulanması. Journal of Research in Education and Teaching, 3(3), 371-378.

Koçak, D. (2013). Farklı yönergelerle verilen çoktan seçmeli testlerde yanıtlama davranışlarının incelenmesi (Yayımlanmamış yüksek lisans tezi). Ankara Üniversitesi Eğitim Bilimleri Enstitüsü, Ankara.

Milli Eğitim Bakanlığı (2017). Eğitim istatistikleri. http://sgb.meb.gov.tr/www/icerik_goruntule.php?KNO=270 adresinden erişilmiştir.

Milenkovic, D. D., Hrin, T. N., Segedinac, M. D., and Horvat, S. (2016). Development of a three-tier test as a valid diagnostic tool for identification of misconceptions related to carbohydrates. Journal of Chemical Education, 93(9), 1514-1520.

Nachtigall, D. (1990). What is wrong with physics teachers' education? European Journal of Physics, 11(1), 1-14.

Organization for Economic Co-operation and Development. (2006). Assessing scientific, reading and mathematical literacy: A framework for PISA 2006. France: OECD Publishing.

Özkan, M., and Bal, A. P. (2017). Analysis of the misconceptions of $7^{\text {th }}$ grade students on polygons and specific quadrilaterals. Eurasian Journal of Educational Research (EJER), 67, 161-182.

Palut, Z. (2006). Fen ögrretiminde aktif ögrenmenin kavram yanılgılarını gidermeye etkisi (Yayımlanmamış yüksek lisans tezi). Marmara Üniversitesi Eğitim Bilimleri Enstitüsü, İstanbul.

Pehlivan, E. B. ve Kutlu, Ö. (2014). Türkçe test maddelerinde yanıtlama davranışlarının incelenmesi. Ĕ̌itimde ve Psikolojide Ölçme ve Değerlendirme Dergisi, 5(1), 61-71.

Reys, B. J., Reys, R. E., ve Penafiel, A. F. (1991). Estimation performance and strategy use of Mexican $5^{\text {th }}$ and $8^{\text {th }}$ grade student sample. Educational Studies in Mathematics, 22(4), 353-375.

Şimşek, N. T. ve Kutlu, Ö. (2017). Ortaokul öğrencilerinin açık uçlu maddelerdeki yanıtlama davranışlarının belirlenmesi. Eğitim Bilimleri Araştırmaları Dergisi, 7(1), 253-262.

Taşlıdere, E., Korur, F. ve Eryılmaz, A. (2012). Kavram yanılgılarının üç aşamalı sorularla farklı bir şekilde değerlendirilmesi. 
http://kongre.nigde.edu.tr/xufbmek/dosyalar/tam_metin/pdf/2312-29_05_201214_14_13.pdf adresinden edinilmiştir.

Tekkaya, C., Çapa, Y. ve Yılmaz, Ö. (2000). Biyoloji öğretmen adaylarının genel biyoloji konularındaki kavram yanılgıları. Hacettepe Üniversitesi Eğitim Fakültesi Dergisi, 18(18), 140-147.

Tokat, Y. (2006). Çoktan seçmeli testlerde yanıtlama davranışlarının belirlenmesi (Yayımlanmamış yüksek lisans tezi). Ankara Üniversitesi Eğitim Bilimleri Enstitüsü, Ankara.

Turgut, M. F. ve Baykul, Y. (2012). Eğitimde ölçme ve değerlendirme. Ankara: Pegem Akademi Yayınları.

Turgut, M. F. (1971). Şans başarısının test puvanlarına etkisi. Ankara: Orta Doğu Teknik Üniversitesi Yayınları.

Ubuz, B. (1999). 10. ve 11. sınıf öğrencilerinin temel geometri konularındaki hataları ve kavram yanılgıları. Hacettepe Üniversitesi Eğitim Fakültesi Dergisi, 17(17), 95-104.

Uğur, U. K. (2010). Lise öğrencilerinin sindirim sistemi ile ilgili kavram yanılgılarının iki aşamalı testler ile tespit edilmesi (Yayımlanmamış yüksek lisans tezi). Selçuk Üniversitesi Eğitim Bilimleri Enstitüsü, Konya.

Umay, A. (1998). Seçmeli derslerde yanıtlayıcı davranışları ve şans başarısının elimine edilmesi işlemlerine ilişkin bazı öneriler. Hacettepe Üniversitesi Eğitim Fakültesi Dergisi, 14(14), 54-61.

White, R. T., Gunstone, R. F., and Oversby, J. (1994). Probing understanding. International Journal of Science Education, 16(1), 123-124.

Yenilmez, K. ve Ata, A. (2013). Matematik okuryazarlı̆ğ dersinin öğretmen adaylarının matematik okuryazarlığı özyeterliğine etkisi. The Journal of Academic Social Science Studies, 6(2), 1803-1816.

Yenilmez, K. ve Yaşa, E. (2008). İlköğretim öğrencilerinin geometrideki kavram yanılgıları. Uludağ Üniversitesi Eğitim Fakültesi Dergisi, 21(2), 461-483.

Yılmaz, A. ve Morgil, F. İ. (2001). Üniversite öğrencilerinin kimyasal bağlar konusundaki kavram yanılgılarının belirlenmesi. Hacettepe Üniversitesi Eğitim Fakültesi Dergisi, 20(20), 172-178. http://www.efdergi.hacettepe.edu.tr/yonetim/icerik/makaleler/1003published.pdf adresinden edinilmiştir. 


\title{
Investigation of The Relationship Between Misconceptions and Answering Behaviors on The Example of The Mathematical Literacy ${ }^{1}$
}

\begin{tabular}{|c|c|c|}
\hline $\begin{array}{l}\text { ARTICLE TYPE } \\
\text { Research Article }\end{array}$ & $\begin{array}{c}\text { Accepted Date } \\
12.04 .2019\end{array}$ & $\begin{array}{c}\text { Published Date } \\
04.01 .2020\end{array}$ \\
\hline \multicolumn{3}{|c|}{$\begin{array}{l}\text { Emre Kucam iD }{ }^{2} \\
\text { Private Zafer College }\end{array}$} \\
\hline & $\begin{array}{l}\text { Ergül Demir iD } \\
\text { Ankara University }\end{array}$ & \\
\hline
\end{tabular}

\begin{abstract}
The aim of this research was to determine the relationship between conceptual misconceptions in math literacy skills of secondary school eighth grade students and their answering behaviors which they used in responding to questions. This is a correlational research. The sample of the research consists of 340 students who are educated in the eighth grades of three schools in the provinces of Çankaya, Etimesgut and Yenimahalle in Ankara. Personal Information Form and Two-Tier Diagnostic Test were used in order to determine the conceptual misconceptions of students in mathematical literacy and the Responsive Behavior Form was used to determine which behavior was used to respond to the answers. All these tools were developed by the researcher to collect information about the students. In the analysis of the data obtained from the research, descriptive statistics and chi-square analysis were used. According to research findings; the students who have misconceptions mostly used elimination answering behaviors and the students who do not have misconceptions used calculation and elimination behaviors. When answering behaviors are analyzed according to the types of misconceptions, it is determined that the random marking is the most used in the type of over-specialization misconceptions and in the case of the other misconceptions types, the most random marking answering behaviors are used. Furthermore, it was determined that the types of misconceptions and answering behaviors did not differ according to the gender, and that the answering behavior of the students did not differ according to the city they were in.
\end{abstract}

Keywords: Misconception, respondent behavior, mathematical literacy, test, two-tier diagnostic test.

\footnotetext{
${ }^{1}$ This article is from a part of a master dissertation of the first author.

${ }^{2}$ Corresponding Author: Specialist, E-mail: emrekucam@gmail.com, https://orcid.org/0000-0002-42837103

${ }^{3}$ Assoc. Prof. Dr., Faculty of Educational Sciences, Departmant of Educational Sciences, E-mail: erguldemir@ankara.edu.tr, https://orcid.org/0000-0002-3708-8013
} 


\section{Purpose and Significance}

In this study, it is aimed to determine the relationship between conceptual misconceptions in math literacy skills of secondary school eighth grade students and respondent behaviors which they used in responding to questions. Conceptual misconceptions are the perceptions and insights that are far from the view that experts agree on a subject in the literature (Hammer, 1996). It is known that the factors such as cognitive level and learning strategy of students cause misconceptions. Therefore, it was aimed to investigate which strategies were used in answering the questions and that these strategies combined with the obstacles became misconceptions. So it is not possible to say that if the marking in multiple-choice tests is correct, the respondent does not have the expected behavior. This raises the suspicion of misconception about the substance that is answered correctly in any way. When the studies related to misconceptions are taken as a whole, it is seen that generally two-tier diagnostic tests are used to determine the errors and according to the responses given to the items in these tests, the level and state of misconceptions are determined according to the criteria determined by the researcher. In the current study, the general situation related to these reasons, which the students who believe in the correctness of their answers, believe in their misconceptions, were asked. When the literature is examined, it is seen that there are separate studies related to misconceptions and response behaviors. However, in the literature, there is no study that discusses misconceptions and respondent behaviors together.

\section{Method}

This research is conducted relational research model because the relationships between misconceptions and respondent behaviors are examined. The relational research model is a research model that aims to determine the relationship between two and more variables and/or to determine the degree of the relationship (Fraenkel and Wallen, 2006).

Non-stratified sampling of the purposive sampling methods was used in this study. The participants of this study were $8^{\text {th }}$ grade students attending in public secondary schools in three districts of Ankara. The data were collected from 390 students. Considering that the test consisted of substances that measure high-level behaviors, 60 two-tier items were applied to 272 students in Ankara, Çankaya, Yenimahalle and Etimesgut districts. In the analysis of the results of the trial application, the clauses and difficulties for each form were calculated separately for the answer part which was scored separately for the multiple-choice part. In the main practice, after the explanation of the rationale for each item in the 16 items two tier mathematics literacy test obtained as a result of the calculations, the box left blank was asked to write the number of the corresponding responder behavior used. In order to determine these behaviors, the form of the respondent behaviors used in the studies to be conducted was taken into consideration while other limited numbers of researches were taken as reference (Turgut and Baykul, 2012; Umay, 1998). In the two-tier diagnostic test developed by the researcher, possible misconceptions about 
mathematics literacy were observed. This test was developed in accordance with test development stages based on classical test theory.

\section{Results}

The first sub-problem in this study is how the distribution of misconceptions is based on misconception types. As a result of the analyzes made for this purpose, those who have a type of misconception, two types of misconceptions, three types of misconceptions, four types of misconceptions and the number of students who have no misconceptions are given in Table 1.

Table 1

The Distribution of The Number of Students With Misconceptions According to Misconception Types

\begin{tabular}{|c|c|c|c|c|c|}
\hline \multicolumn{3}{|c|}{ Misconception Types } & $\mathbf{N}$ & $\begin{array}{l}\% \\
\text { (Total) }\end{array}$ & $\begin{array}{l}\% \text { (Inside of } \\
\text { Misconceptions) }\end{array}$ \\
\hline \multicolumn{3}{|l|}{ Overgeneralization } & 0 & 0 & 0 \\
\hline \multicolumn{3}{|l|}{ Overspecification } & 0 & 0 & 0 \\
\hline \multicolumn{3}{|l|}{ Mistranslation } & 0 & 0 & 0 \\
\hline \multicolumn{3}{|l|}{ Limited Conception } & 0 & 0 & 0 \\
\hline \multicolumn{3}{|c|}{ Overgeneralization and Overspecification } & 0 & 0 & 0 \\
\hline \multicolumn{3}{|c|}{ Overgeneralization and Mistranslation } & 0 & 0 & 0 \\
\hline \multicolumn{3}{|c|}{ Overgeneralization and Limited Conception } & 32 & 9.4 & 9.7 \\
\hline \multicolumn{3}{|c|}{ Overspecification and Mistranslation } & 0 & 0 & 0 \\
\hline \multicolumn{3}{|c|}{ Overspecification and Limited Conception } & 4 & 1.3 & 1.4 \\
\hline \multicolumn{3}{|c|}{ Mistranslation and Limited Conception } & 11 & 3.2 & 3.3 \\
\hline \multicolumn{3}{|c|}{ Overgeneralization, Overspecification and Mistranslation } & 1 & 0.3 & 0.3 \\
\hline \multicolumn{6}{|l|}{$\begin{array}{l}\text { Overgeneralization, } \\
\text { Conception }\end{array}$} \\
\hline \multicolumn{5}{|c|}{ Conception } & 4.1 \\
\hline \multicolumn{3}{|l|}{$\begin{array}{l}\text { Overspecification, } \\
\text { Conception }\end{array}$} & 6 & 1.7 & 1.8 \\
\hline \multicolumn{3}{|l|}{ All Types } & 123 & 36.1 & 37.2 \\
\hline \multicolumn{3}{|l|}{ Any Types } & 14 & 4.1 & 4.3 \\
\hline \multicolumn{3}{|l|}{ Total } & 340 & 100 & \\
\hline
\end{tabular}

The students who have misconceptions as a result of the chi-square analysis performed to determine whether there is a significant difference between the respondent behaviors of the students observed and not observed is the elimination behavior, they have shown in 12 of the 16 items, while the least they show is the nonresponse behavior. Students who do not see misconceptions are the most common elimination behaviors in 9 out of 16 items, and at least they show random marking behavior. From this point of view, it can be stated that those who have misconceptions do not show the response behavior and those who have no misconception show this 
behavior type more. In addition, the respondent behaviors of the students in each item differ according to their misconceptions. In other words, respondent behaviors do not show similar distribution in terms of misconceptions.

In general, students with misconceptions often use sifting behavior and students who do not misconceptions use transactional and elimination behaviors. In addition, it was observed that the students who had no misconceptions had a much higher rate of random marking behaviors than the students who had misconceptions. When this situation is considered together with the definition of misconception, it can be stated that the students who have misconceptions make less random marking is a consistent result. This suggests that students who do not have the error show a random marking behavior without qualifying if they are unsure of their knowledge. This is in line with the findings of Kadığlu (2002) and Pehlivan and Kutlu (2014).

When the respondent behaviors of all students according to misconceptions are taken into consideration; it was determined that the most elimination behaviors in extreme generalization, misinterpretation and restricted perception misconceptions were the most random marking behavior. In the case of excessive customization misconception, it was determined that the random marking behavior was shown to be at least. Based on these results, it can be seen that these items are very difficult for students when the difficulties of the type of hypersensitivity misconception are examined. When the types of substance-based misconceptions are considered, the result obtained above can be expressed as less than those who have misconceptions in each responding behavior.

Students who have misconceptions and who reach the result by processing are the ones who mostly respond to items with limited perception, who have misconceptions and reach the result by screening most of the students who responded to the items of overspecification, misconceptions and those who left the relevant items unanswered, responded to the items of the overspecification. In addition, when the distribution of responder behaviors according to misconceptions is examined in general, it is seen that the types of respondents who are the most marked in each of the four misconceptions are determined by sieving.

Misconceptions do not show a significant difference according to gender in general. The answer of male students are the ones who respond most frequently in 12 of the 16 items, while the respondents' behavior is the least. The female students are the ones who most respond to the respondents' behavior in 12 of the 16 items, while the respondents' behavior is the least. It can be stated that the respondent behaviors of students do not differ according to their status as women or men. The large number of responding behaviors means that there is a lot of guessing behavior among the options. In Reys, Reys and Penafiel (1991), it was found out that there was no difference in predictive skills according to gender in Grade 8 students. This result supports the research. 
The distribution of the misconceptions experienced by the students taking the two-tier diagnostic test according to the district where the students are located, the schools in Çankaya and Yenimahalle generally do not show misconceptions in 12 of the 16 items. It is observed that the students in schools in Etimesgut generally do not show a misconception in 14 of 16 items, while the least misconception is the type of misconception. In this context, it can be said that there is no meaningful relationship between the state of showing misconceptions and the districts where the schools are located. From this point of view, it is understood that the types of misconceptions in districts with low socioeconomic level and high socioeconomic status show similar distribution.

\section{Discussion and Conclusions}

According to the findings, the two-tier diagnostic test, which was prepared by Graeber and Johnson (1991) considering the types of misconceptions. It is a misconception that two or more types of misconceptions are seen together. They often have misconceptions in the types of overgeneralization, mistranslation and limited perception misconception, that their misconceptions in the type of overspecification are relatively less, that their response behaviors differ depending on and the nonmisconceptions of the students. But the students who have misconceptions show the least unresponsive behavior. This shows that the students with misconceptions are sure that they know what they know when they are confident. The concept of misconceptions is overlapping with the definition of misconception. The use of the most random marking behavior in the overspecification misconception; overgeneralization, mistranslation and limited perception types are the most sifting behavior; when the items belonging to the type of overspecification are examined, it is thought that the difficulties of the item are high (hence the random marking in the case of overspecification is an important result).

Based on the findings of this study, some suggestions can be made to the field of application, to the researchers who will do research on similar subjects and to the institutions. In this context, the relationship between misconceptions and response behaviors should be considered. It is possible to understand the level of responding behaviors by looking at misconceptions. There is also the possibility to understand the type of misconceptions by looking at their response behaviors. Considering the fact that students with misconceptions often show sifting behavior (chance of mixing of chance factors), the type of test to be applied can be decided according to the respondent's behavior. Misconceptions can be determined more effectively with the appropriate test type. The pre-test application to determine the misconceptions and misconceptions of the students before the teaching activities can be effective in order to determine the mental processes of the students in a more healthy way and to take necessary precautions.

Some suggestions can be made for other research. In this context, multistage tests ( 3 and 4 stages) can be applied in this research limitation despite the difficulties of use. In addition, as the cognitive level measured by the items increases, the 
predicted behavior of the students decreases. Practitioners can, therefore, focus on substances that measure high-level skills to be used in tests to reduce predictive behavior. This research was carried out with the participation of $8^{\text {th }}$ grade students from the secondary schools in three districts of Ankara. A similar study can be done in private and public schools and the results can be compared. In addition, considering that this study was conducted with $8^{\text {th }}$ grade students in secondary school, it is thought that conducting similar studies at secondary and undergraduate levels will contribute to the field. In this research, the relationship between misconceptions and respondents' behaviors were examined. New studies can be done by taking into account other variables (success, attention, attitude etc.) which may be related to misconceptions. 